\title{
\#IfTheyGunnedMeDown: The Double Consciousness of Black Youth in Response to Oppressive Media
}

\section{Nora Gross}

To cite this article: Nora Gross (2017) \#IfTheyGunnedMeDown: The Double

Consciousness of Black Youth in Response to Oppressive Media, Souls, 19:4, 416-437, DOI: 10.1080/10999949.2018.1441587

To link to this article: https://doi.org/10.1080/10999949.2018.1441587

Published online: 18 Apr 2018.

Submit your article to this journal $\pi$

Q View related articles $\longleftarrow$

View Crossmark data $₫$ 


\title{
\#IfTheyGunnedMeDown: The Double Consciousness of Black Youth in Response to Oppressive Media
}

\author{
Nora Gross
}

Following the death of Michael Brown, an unarmed Black teenager, at the hands of a white Ferguson police officer in 2014, a social media hashtag emerged drawing attention to the power (and potential bias) of the media in representing Black youth. \#IfTheyGunnedMeDown asked the semi-rhetorical question, "Which picture would the media choose to represent me if I were killed by police?" and offered a choice between two contrasting images-one a presumably positive representation and the other stereotypically negative. Through a content analysis of 100 pairs of juxtaposed images from the first 24 hours of the hashtag, I examine the ways Black youth negotiate oppressive media representations and produce their own self-images. Through their strategic political response, the users of the hashtag demonstrate their "double consciousness" in a Du Boisian sense as well as their acute understanding of the specific symbols that mark a Black body as threatening and those that mediate the supposed threat. In doing so, however, they expose the limited number of templates available to them for performing an identity interpreted positively by the mainstream media and broader social world, as well as the continuing role of respectability politics in shaping public perceptions of Black youth.

Keywords: Black youth, double consciousness, race, representation, respectability politics, social media, social movements, visual sociology

On the afternoon of August 9, 2014, Michael Brown, an unarmed Black teenager, was shot and killed by a white police officer after a brief interaction on the street in Ferguson, Missouri. In the hours and days following the shooting, the story gained national attention through various media, propelling forward the then-nascent Black

Color versions of one or more of the figures in the article can be found online at www.tandfonline.com/usou. 
Lives Matter movement. Many news outlets initially represented Michael Brown with a photograph culled from his Facebook profile that showed the teen wearing a red Nike Air tank top and light-colored pants. The low camera angle made Brown look particularly large and, to some, menacing-especially since he was holding out his right hand in an ambiguous three-finger gesture. Within hours of the first news story, sectors of social media erupted with criticism of the image choice. The photograph, they argued, was intentionally selected to make viewers feel that Brown deserved his fate. In response, many TV stations switched their visual representation of the victim to another image: a close-up of Brown's face in three-quarter profile, gazing into the lens wearing headphones and a neutral expression.

By the following morning, a social media hashtag emerged drawing attention to the power and potential bias that the media has in representing people after they have died in general-and Black people who have been killed by the police in particular. The hashtag, \#IfTheyGunnedMeDown (abbreviated here to \#ITGMD), asked the semi-rhetorical question, "Which picture would the media choose to represent me if I were killed by the police?" and offered a choice between two contrasting images-one positive, socially acceptable, and suggestive of innocence; and the other put forth as the stereotypically negative or problematic representation the media might prefer. [As a shorthand, in this article I will refer to the image types as "(socially) acceptable" and "(socially) problematic," referencing the way they are presumably presented by the tweeter posting them in the structural arrangement of the \#ITGMD exercise.] Across social media sites like Twitter, Facebook, Instagram, and Tumblr, young people of color (and others) around the country began posting paired photographs of themselves tagged with the \#ITGMD hashtag.

The activist hashtag was conceived on August 10 by criminal defense lawyer C.J. Lawrence who juxtaposed two photographs of himself (Figure 1) - one giving a college graduation speech with Bill Clinton seated behind him (and laughing), and the second dressed as rapper Kanye West for Halloween. In an interview with the $\mathrm{BBC}$, Lawrence described his post as a critique of the way images can shape perception and shift blame away from the police and onto victims, especially when they are Black. ${ }^{1}$ Within 48 hours, the phrase \#IfTheyGunnedMeDown was used on Twitter 168,000 times. $^{2}$ Some particularly popular posts (e.g., Figure 2) were shared and "retweeted" thousands of times.

As a social media-driven effort within a larger context of contemporary Black activism, ${ }^{3}$ the \#ITGMD posts offer an unusual opportunity to see Black youth "yelling back" at mediatized events ${ }^{4}$ and sharing a visual counternarrative to what they perceive as the devaluation of their lives by the media and larger public. This article will examine a sample of the \#ITGMD image pairs from the earliest hours of the hashtag's use in order to understand the ways that Black youth and young adults negotiate oppressive media representations and produce their own selfimages. Through a content analysis of 200 images, I will describe patterns across the photographs advanced as both "socially acceptable" and "socially problematic" representations. I will argue that through this visual political response, the young men and women using this hashtag demonstrate a kind of "double consciousness" 


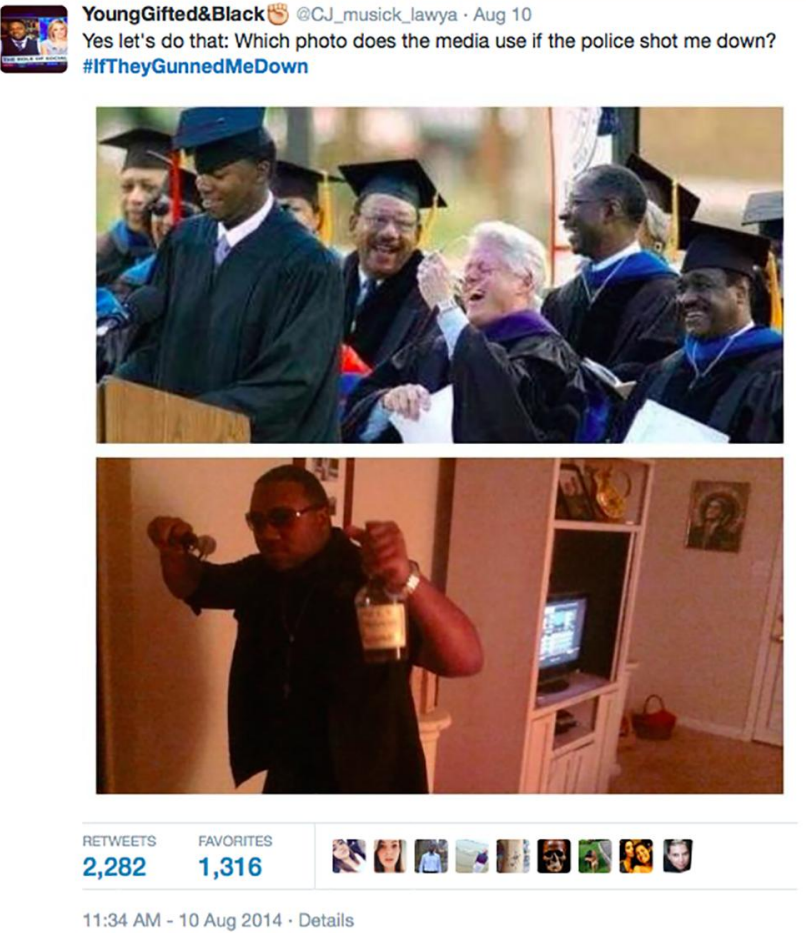

Figure 1 The first post using the hashtag \#IfTheyGunnedMeDown, from C. J. Lawrence. Reproduced by permission of this Twitter user.

about their racialization in the eyes of a white public as well as an acute understanding of the specific symbols that mark their bodies as threatening or innocent. In doing so, however, they expose the limited number of templates available to Black youth for performing an identity interpreted positively by the larger social world, as well as the continuing role of the politics of respectability in shaping public perceptions of Black people.

\section{The Legacy of Visual Resistance}

Just as race is itself a visible marker "eminently embodied and visual,"5 visuality and imagery have historically played a significant role in the racialization of African Americans. Since its invention, the power of photography has been harnessed to further racist agendas, such as with the slave daguerreotypes used to promote mid-19th-century "race science." 6 These photographs and others actually helped "condition a modern way of seeing" and contributed to the construction of a monolithic image of African Americans as less than human. ${ }^{7}$ As Fleetwood posits, "the visible black body is always already troubling to the dominant visual field," and media often plays a part in maintaining or amplifying that "trouble" through their tools of representation. Marginalized groups are often invisible, but in cases 


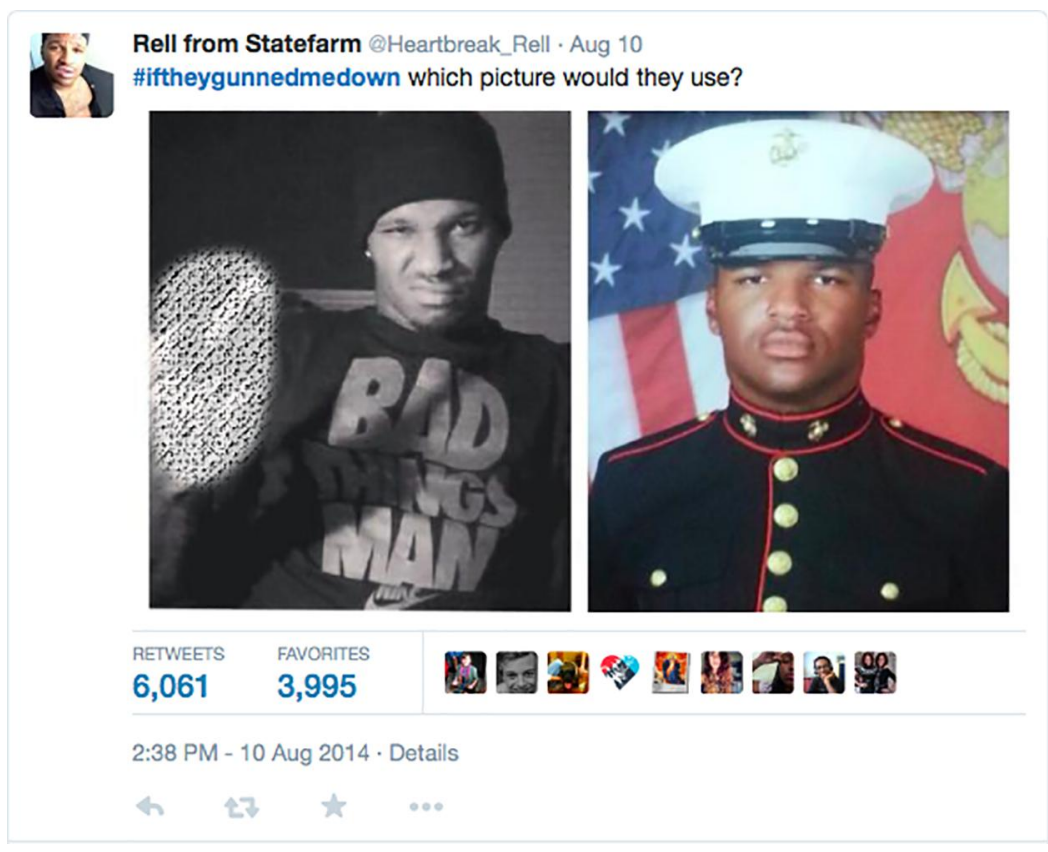

Figure 2 One of the most retweeted posts with this hashtag. (Note: At the request of this Twitter user, his hand gesture [left] has been obscured; however, the original post can be easily found online.) Reproduced by permission of this Twitter user.

when they do achieve some semblance of visibility, their representation "will itself reflect the biases and interests of those elites who define the public agenda" perhaps like the initial image of Brown chosen by the media.

And yet, photographs have also served as mechanisms for uplift from misrepresentation or objectification. Frederick Douglass, for instance, believed that African Americans who had formerly been enslaved could contest and reverse the social death of slavery through photography. He argued that the camera could return the gaze of the oppressor, show the humanity of the African American people, and "reveal the scope of human similarity across difference." ${ }^{10}$ Other artistic forms of resistance-including poetry and literature, theater and film, and material practices-have been used to counter anti-Black visual representations and produce dignified self-representations. ${ }^{11}$ Even when human value is not fully recognized by a wider public, ordinary people still find ways within their own communities to "ascribe value to the devalued through visual languages." ${ }^{2}$

Individuals have also mobilized the media itself to show the brutality of white supremacy as inflicted upon the bodies of Black individuals. In 1955, when 14-year-old Emmett Till was kidnapped, tortured, and brutally murdered in Mississippi by three white men for allegedly whistling at a white woman, his mother Mamie Elizabeth Till-Mobley made the unorthodox decision to have an open casket funeral. Further, she invited photographer David Jackson of Jet magazine to photograph the funeral and her son's corpse. The resulting images of Till's 
horrifically brutalized face, which were published widely, were often juxtaposed with pictures of him while living, well-dressed and buttoned up, his joyful smile and bright eyes emanating youthful innocence. This photographic doubling was Mamie Till's strategic effort to harness the power of the media to reclaim the narrative of her son's murder and expose its horrors on her own terms. Drawing the connection between the photographs of Emmett Till and imagery of present-day police (and white) brutality toward Black people, Bryan Stevenson proposes that "without the imagery, there would be no one who's prepared to believe some of the violence that we've witnessed." 13

Another way that imagery was used strategically to resist systemic injustice and the dehumanization of Black people in the 20th century was through the "respectable" presentation of self by Civil Rights leaders. In her analysis of the circulating imagery of Rosa Parks, Fackler argues that "the visual staging of respectability became a central concern for the movement" and impacted the way Parks was photographed. ${ }^{14}$ An emphasis on respectability can also be understood more broadly in the very choice of Parks as the face of the Montgomery Bus Boycott over, for example, 15-year-old Claudette Colvin who was arrested for refusing to give up her seat on a public bus nine months before Parks staged the same protest. In a recent interview, Colvin, who is now in her 70s, explains: "I knew why they chose Rosa. They thought I would be too militant for them. They wanted someone mild and genteel like Rosa," ${ }^{\prime 15}$ who was secretary of her National Association for the Advancement of Colored People chapter at the time, married, and working as a seamstress. It was not just their age, temperament, and lifestyle differences, but also physical appearance: "Her skin texture was the kind that people associate with the middle class," 16 Colvin said in an interview. In mannerisms, dress, and overall appearance-particularly as documented in photographs-Parks better countered the prevailing stereotypes of Black women.

The attention to self-presentation that was so vital to the Civil Rights Movement was portended by early 20th-century organizations like the Woman's Convention of Black churchwomen of the National Baptist Convention and the National Association of Colored Women. The women in these groups invoked a "politics of respectability" in their efforts to counter racist and sexist stereotypes by defining themselves through the presentation of an impeccable moral character-a tool that was especially useful to the poor since they had few other stances from which to demand respect. Evelyn Brooks Higginbotham, who coined the term, argues that the reforming of "individual behaviors and attitudes" involved in the politics of respectability was both a "goal in itself" and a "strategy for reform of the entire structural system of American race relations," particularly that which viewed Black women as, not only less than fully human, but also hypersexual. ${ }^{17}$ As a Black person at the time, the very claim to respectability was a "subversive" act. ${ }^{18}$

Higginbotham shows that promoting a "respectable" image of Black folks required that the Black Baptist women not only contest whites' perceptions of them, but also "condemn ... what they perceived to be negative practices and attitudes among their own people." 19 However, despite critiques that this approach promoted intraracial 
divisions around class or status and adherence to traditional gender norms, scholars have argued that it was a productive strategy for resistance: "the moral attractiveness of the civil-rights movement did convert some people, and negative perceptions of African Americans were altered by the dignified character of black protests" ${ }^{20}$ and perhaps also through the self-presentation of people like Rosa Parks and the imagery of people like Emmett Till.

The contemporary Twitter posts under study here implicitly demonstrate both of these documented uses of the photographic image: as an instrument of objectification and dehumanization and as a tool for resistance and social uplift. In fact, \#ITGMD's power as a visual exercise derives from this very duality and juxtaposition. The posts actualize a version of W. E. B. Du Bois' concept of "double consciousness," which is a Black American experience "of always looking at one's self through the eyes of others, of measuring one's soul by the tape of a world that looks on in amused contempt and pity." ${ }^{21}$ African American subjectivity, in other words, is "divided by contending images of blackness" 22 -images produced through dominant white narratives, and those constructed and maintained within Black communities. The \#ITGMD tweets, as a contemporary "circulation" of Blackness, ${ }^{23}$ exhibit a sophisticated understanding of the kinds of racialized perceptions of Black youth that exist beyond the "veil" or "one-way mirror" that separates the races, ${ }^{24}$ as well as an effort to resist and revise those perceptions.

\section{Black (Youth) Protest in the Digital Age}

The lives of Black youth today are rife with contradictions. How do young people, as Cathy Cohen puts it, "make political sense of an environment in which more black youth than ever before are in college at the same time that more black youth than ever before are in prison?" 25 How do they reckon with the rise of a Black man to the most powerful position in the world simultaneous to a seemingly exponential rise in the visibility of Black death? State-sponsored violence against Black people is as old as our country itself, as are the protests, riots, and rebellions in their wake, ${ }^{26}$ but the increasing presence of video and photographic evidence has pushed the issue of police brutality (and other white supremacist violence) into the mainstream spotlight in recent years. Along with it, a "new Civil Rights Movement," as some have termed it, has arisen in the form of Black Lives Matter and the Movement for Black Lives.

After the July 2013 acquittal of neighborhood watch volunteer George Zimmerman in the murder of unarmed teen Trayvon Martin, Alicia Garza, an Oakland activist for domestic workers' rights, wrote a heartfelt Facebook post concluding with the words, "Black people. I love you. I love us. Our lives matter." Patrisse Cullors, a fellow California-based organizer, responded with the hashtag \#BlackLivesMatter. Shortly thereafter, the two, joined with immigrant rights activist Opal Tometi in New York, began organizing a campaign around those ideas. ${ }^{27}$ Though Black Lives Matter (BLM) began with a Facebook post and then a hashtag, it has developed into a member-led global network of more than forty chapters organizing on- and offline 
protests and making intersectional policy demands in support of all Black lives. In just a few short years, BLM has become a "shorthand for diverse organizing efforts-both sporadic and sustained-across the country." 28

BLM, and related contemporary protest movements, aim to counter the respectability politics of prior generations. ${ }^{29}$ They advocate for the valuing and centering of all Black lives, even those who do not conform to mainstream or middle class "norms of civility" ${ }^{30}$ in the form of dress or speech or education level or who have previously "been marginalized within Black liberation movements." 31 This, BLM hopes, will move the focus of change away from individual behavior modifications and onto structural solutions. As an illustration, at the same time as journalists and others emphasized the fact that Michael Brown was a week away from beginning college when he was killed, others pointed to the way this framing of the victim reinforced a politics of respectability. One online commentator wrote, "I wouldn't have cared if Mike ... sagged [his] pants down to [his] ankles and if the only image of [him] depicted [him] smoking pot and throwing gang signs.... [His life] would have been every bit as valuable, and [his loss] every bit as infuriating and sad." 32 Today's young activists realize that respectability - whether in the form of a fancy degree, a good job, a suit and tie, or perfect Standard English-is unlikely to prevent continued antiBlack state violence without meaningful structural changes to American society. ${ }^{33}$

The BLM generation's skepticism of respectability politics and their commitment to an "inclusive and spacious movement" 34 has sometimes been met with criticism from the Black political elite, including former President Obama. After the Ferguson grand jury refused to indict the officer who killed Michael Brown, a new round of protests began on the city's streets, as well as across the country. The protests reflected the grievances of young people "whose future was being stolen by the never-ending cycle of fines, fees, warrants, and arrests" and who resented the incompetence of elected officials at helping improve conditions in low-income communities of color. ${ }^{35}$ In Obama's speech just a few minutes after the grand jury announcement, he chastised the young protesters, who do not "look like ... traditional civil rights demonstrator[s]," 36 for their behaviors, telling the crowd that progress will not be accomplished "by throwing bottles [or] smashing car windows. That won't be done by using this as an excuse to vandalize property. And it certainly won't be done by hurting anybody." 37

The division between Black politicians and young Black activists has played out even more recently as New Jersey lawmakers, led by an African American female assembly member, pushed for a 2017 vote on a bill that would require schools to teach children how to interact with police "properly." In other words, students would now get "the talk" about negotiating public interactions while Black, that usually comes from parents, in school. Alexis Miller, a BLM organizer in Paterson, NJ opposes the bill and argues that it suggests that "children are expected to master the idea of respectability politics in order to protect themselves from officers," taking accountability off the police themselves. ${ }^{38}$ On the other hand, Randall Kennedy argues that it is a necessary effort to protect children from danger even when one recognizes "that the need to expend energy to avoid that danger [is] itself an unfair product of racism." 39 The politics of respectability, he goes on to propose in 
opposition to this new generation of activists fighting for Black communities, is "a tactic of public relations" that can be misapplied but is generally productive. ${ }^{40}$

Even within the BLM movement, there are political fissures, particularly around gender and sexuality. Despite the centrality of women to both the founding and the leadership of BLM, both supporters and corporate media continue to "frame the struggle in terms of a putatively masculine prerogative of self-defense." 41 Being a Black queer women, BLM co-founder Alicia Garza proposes, "tends to equal invisibility and nonrelevancy" 42 as protests are mobilized around male victims of police violence at the exclusion of the narratives of trans and women victims. Even online, men's tweets in relation to Ferguson were more frequently retweeted and mentioned. ${ }^{43}$ Activists have used Twitter campaigns like \#SayHerName to attempt to keep the movement inclusive of all Black people across gender lines. ${ }^{44}$

Indeed, Twitter is one of the primary spaces in which Black (millennial) activism is shaped at present. Created in 2006, Twitter is a microblogging site with over 500 million registered users, including $23 \%$ of online U.S. adults. ${ }^{45}$ Like many other social media applications, Twitter is most popular with younger adults; unlike many other platforms, however, Twitter draws from a disproportionately Black base, ${ }^{46}$ and is home to what has come to be known as "Black Twitter," a community of cultural critics, celebrities, academics, journalists, and youth who engage in conversation about race and Black culture. ${ }^{47}$ The community has functioned as a space-a "counterpublic," as some have $\operatorname{argued}^{48}$-for solidarity building, information sharing, cultural critique, and activism.

One particularly popular tool for Twitter activism is the hashtag. In the last several years, numerous racialized hashtags_or "Blacktags" 49 - have sprouted up in response to current events affecting the Black community. ${ }^{50}$ Their intent may be, to cite a few examples, to show racial solidarity (i.e., \#IAmTrayvon), critique racist bias at an industry level (i.e., \#OscarsSoWhite), or connect with a larger activist movement happening both on- and offline (i.e., \#BlackLivesMatter). The use of hashtags serves an "amplifying" function, not only as "a filing system" for sorting and retrieving disparate posts on a single topic, but also as a "semiotic" marker allowing users to "performatively frame what [their] comments are 'really about' [and] indicate a meaning that might not be otherwise apparent." ${ }^{21}$ And this framing can, in certain contexts, function as "a new semiotics of emancipation" when used as part of a racial justice project. ${ }^{52}$ In the case of \#ITGMD, I echo Bonilla and Rosa in proposing that the hashtag can become a kind of "field site" within which to visualize efforts toward "emancipation" from the media's framing and toward the construction of emic counternarratives about Black youth in the 21 st century. ${ }^{53}$

\section{Methods}

This study employs a visual sociological approach. ${ }^{54}$ By using images that are "deeply grounded in the phenomenology of the subject," 55 I hope to unpack the meaning being constructed and shared through these photographs and the call to action they are issuing. Like Harper, I believe that photographic imagery can be a particularly valuable tool for developing counternarratives about marginalized groups-especially 
when the images are produced by group members themselves-and examining race as a socially constructed, but visually maintained, set of categories. ${ }^{56}$

I employed a variation of cluster sampling ${ }^{57}$ to select 100 posts from the earliest period of the \#ITGMD social media movement on Twitter. By using the Advanced Search function and including the hashtag \#IfTheyGunnedMeDown and date range August 9-10, 2014, I was able to see the earliest 24 hours of the movement. The primary criteria for inclusion in the sample were that it be an original tweet posted by the individual appearing in the pictures, who appeared to be Black and young, ${ }^{58}$ and that it be clear which picture was intended to represent which part of the argumentative juxtaposition (which was almost always the case). This selection process produced a sample that was skewed along gender lines with seventy-eight posts from individuals who present as young men, and twenty-two from those who present as young women. ${ }^{59}$ Although I cannot say whether this gender imbalance is representative of the full population of Twitter users participating in the \#ITGMD exercise, it does align with the common, though not accurate, conflation of police violence with dangers facing Black boys and men.

I use data from the first day of the hashtag since, as prior research has shown, the meanings and tone of activist posts can change within a span of hours or days; ${ }^{60} \mathrm{my}$ interest here is in capturing the original intent of the hashtag in response to the media's representation of Brown and the way this intent was taken up by Black youth and young adults in the immediate moment. Although other relevant hashtags (i.e., \#Ferguson, \#HandsUpDontShoot, \#MikeBrown) were attached to a wide range of tweets serving a multiplicity of purposes, ${ }^{61}$ the specificity of this hashtag-especially on the first day of its use-made the sample selection relatively uncomplicated. After coding, it was clear to me that I had reached saturation and that increasing my sample would not yield additional or different findings. ${ }^{62}$

My primary analytic goal was to look for the expressions given off by the images and identify specific symbols and situations that create these messages. ${ }^{63}$ The majority of my analysis involved looking at patterns across all posts for each type of image, "problematic" and "acceptable," rather than a close study of individual diptychs. ${ }^{64}$ I performed two rounds of content analysis: The first round focused on the quantitative frequency of specific components of the pictures, and involved "the objective, systematic and quantitative description of the manifest content of communication." 65 I analyzed each image across the following domains: the photographs' composition, the situational context, the subjects' clothing, facial expression, gesture, and the objects and associates with whom s/he is posing. Within each domain, I inductively created an exhaustive set of codes (i.e., within clothing: hoodie, $\mathrm{t}$-shirt, bowtie, etc.) and then performed frequency counts for each code. The second coding pass aimed at a more holistic and qualitative understanding of the images and the latent meanings they contain. ${ }^{66}$ This approach gave me the flexibility to interpret elements like the setting or whether or not the subject's outfit was a costume, which required drawing on a number of clues that might otherwise be coded only separately-in other words, my aim was to interpret the "complete gestalt" of the picture. ${ }^{67}$ 


\section{Findings}

I will integrate the two types of coding below, focusing on the trends and patterns across the 200 images, particularly those elements that mark major differences across the "socially acceptable" and "socially problematic" types. ${ }^{68}$ First, it is worth noting that within both types of images, the sample is overwhelmingly made up of posed pictures (178 or $89 \%$ of all images) including forty-two "selfies." The posing here is important because it suggests a performance of self, or at least an awareness of the self being displayed. ${ }^{69}$ Interestingly, selfies were much more common in the posts made by young women, and, across gender, more than twice as common in the pictures presented as "problematic" than in those put forth as "acceptable."

Although nearly all of the pictures appear to be posed, the context for the posing varies substantially between the "socially acceptable" and the "socially problematic" images. All 100 of the images framed as "problematic" depict either informal situations or the contexts are unclear. In contrast, $83 \%$ of the "acceptable" pictures were taken in formal situations, including institutional rituals and ceremonial events, while only $17 \%$ are informal or contextually ambiguous. Even the pictures depicting the subjects informally "hanging out" are different across the two groups: while most of the "problematic" pictures show "hanging out" with peers, the "acceptable" images mostly find the participants "hanging out" with people who seem to be either their mother, their young child, or a white-appearing person. This strategy of choosing as the "acceptable" image one that presented the protagonist in relationship with someone else was more frequently employed by the young men in the sample, occurring in $28 \%$ of the men's "acceptable" pictures and only $14 \%$ of the women's.

In addition to the setting itself, clothing provides another window into the major differences between the two types of pictures. More informal articles of clothing and accessories like t-shirts and tank tops, hats, bandanas and doo-rags, and chains or crosses worn around the neck appear in much greater numbers in the "problematic" images. Hoodies in particular, appear almost exclusively in the "problematic" image, in some cases explicitly referencing Trayvon Martin (e.g., Figure 3, left); in other cases, probably simply for style or warmth (e.g., Figure 4, left). Graduation caps and gowns, military or other professional/work uniforms, and neckties or bowties on men show up exclusively in the "acceptable" images. In fact, the "socially acceptable" images contain very little situational or adornment variation; nearly all of them depict the tweeter either at a school graduation or posing in cap and gown $(29 \%)$; wearing a military uniform or otherwise showing military affiliation $(11 \%) ;{ }^{70}$ participating in a formal ceremony or event $(9 \%)$; posing for a professional or institutional portrait $(10 \%)$; giving a speech or presentation $(5 \%)$; or taking part in a nonspecific formal occasion $(34 \%))^{71}$ These are the only events depicted in nearly $90 \%$ of the "socially acceptable" half of the diptychs.

Facial expression is another area with clear differences between the two categories of photographs. The tweeters are smiling in more than half of the "acceptable" pictures, but only twelve of the other type; exaggerated expressions (like the grimace 


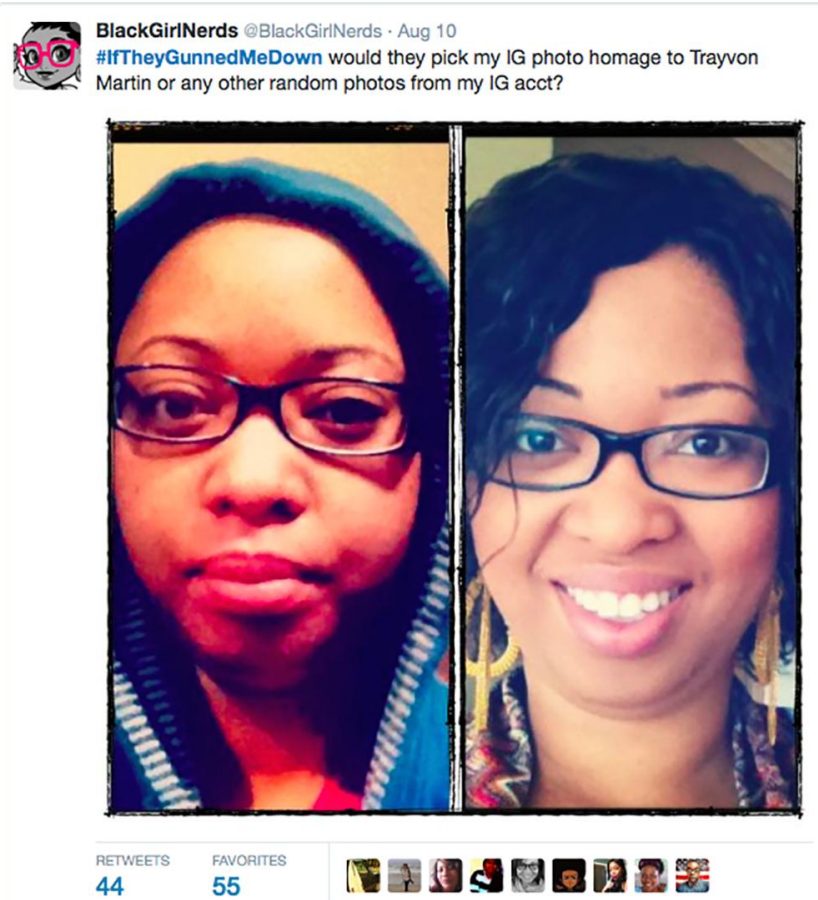

Figure 3 A post from the first day of the hashtag's use. Reproduced by permission of this Twitter user.

in the left-hand picture of Figure 2 or an exposed tongue) only appear in the "problematic" pictures. As we might expect, the men do not smile as much: just under half of the "acceptable" pictures of men show smiles, while close to three quarters of the women's do. However, for some men, a smile is essentially all that makes the difference between a picture they feel the media could weaponize against them in death and another that would paint them more positively.

Like expressions, the presence and arrangement of the tweeters' hands represent straightforward differences between the two image types. Nearly half $(46 \%)$ of the "problematic" pictures contain some kind of hand gesture-either a middle finger, a raised fist or fists, or an ambiguous symbolic contortion of one or both handsall more common in the images of young men. This is compared to just five ambiguous hand gestures in the "acceptable" pictures; in fact, precisely half of the "acceptable" pictures do not reveal the tweeter's hands at all.

Finally, one larger question worth exploring: looking only at the collection of "problematic" images-those put forward by their subjects as examples of how they believe the media might misrepresent them and paint them as somehow deserving of a "gunned down" fate-how many actually represent behavior that is illegal, offensive, or dangerous? ${ }^{72}$ If I take a hugely generous approach to these terms, lumping in all of the images that contain smoking (even if just tobacco), alcohol (even if the drinker appears to be of age), guns (even fake ones), money displayed in any way, 
Pusha Zo @LoRealZo ·Aug 10

\#IfTheyGunnedMeDown which pic would they use?

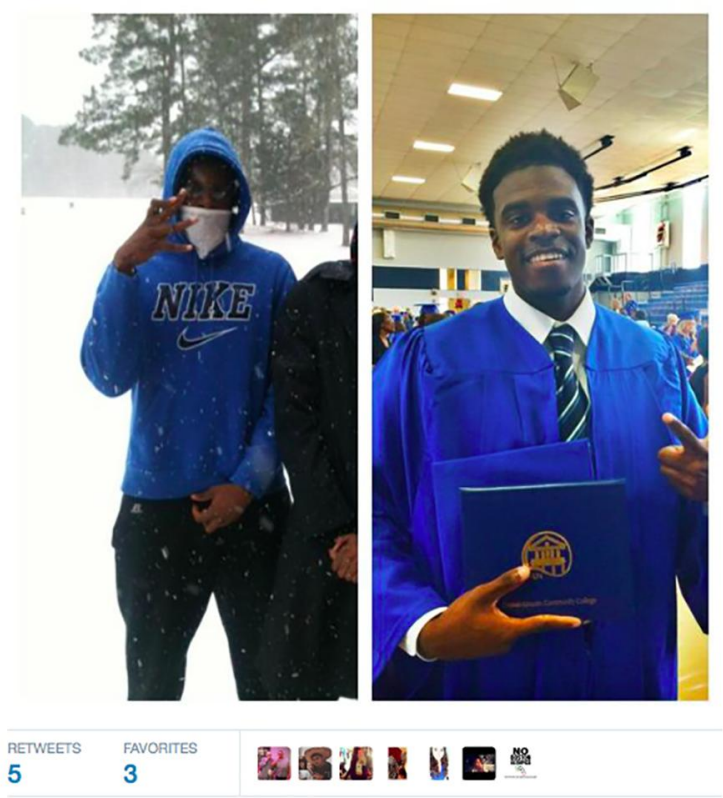

4:49 PM - 10 Aug 2014 - Details

Figure 4 A post from the first day of the hashtag's use. Reproduced by permission of this Twitter user.

hand gestures of any kind (even if they can be easily explained), grimaces, and any obscuring of the face, I can only account for $75 \%$ of the "problematic" images. This means that fully a quarter of the sample (twenty-five images) simply show a young Black person dressed informally and, in all but one case, not fully smiling (e.g., Figure 3). And yet, this informality or neutral expression-the lack of visible institutional affiliation or the outward expression of pleasantness or pleasure-is enough to make these images feel to their protagonist like they could be used as an accusation of wrongdoing.

Interestingly, these unmarked images-those that are framed as "problematic" even without any explicit markers of wrongdoing-are more common among the young men in this sample. The women in their "problematic" pictures are found smoking, drinking, or holding a weapon in higher proportions than their male counterparts. In other words, while the women frequently use "deviant" props to differentiate one version of themselves from the other, many more of the men's juxtaposed images simply involve a change in costume or a contortion of the body (i.e., hand gesture, facial expression). In their positive, or "socially acceptable" selfrepresentations, women also relied more heavily on markers of institutional inclusion, while men relied more on their association with others (presenting themselves as fathers, sons, or friends to an already innocently marked person) or sartorial indicators. ${ }^{73}$ 


\section{Discussion}

What is most striking about the \#ITGMD posts is their "twoness," the way they embody the twin consciousness Du Bois argued Black Americans were both blessed and burdened to possess. For instance, in Figure 5, Val demonstrates her ability to see through her own eyes while also seeing herself as others may see her. When she asks, "Would they say I was gang affiliated or a classy lady?" she is essentially inquiring about whether the world is looking at her with "contempt and pity"74 or if they see her as we may infer she sees herself-“a classy lady." Val, like so many of the other \#ITGMD posters, recognize that, in part because of her age, race, gender, and perhaps class, ${ }^{75}$ the two images may appear quite different to certain audiences.

Those differences, of course, are located in concrete and sometimes minute details of the images. The \#ITGMD tweets, both individually and collectively, reveal their makers' facility with these specific tropes and the way they are interpreted by a white public and its media. The differences can be extreme and seemingly embodied in the different roles we play in everyday life (e.g., Figures 1, 2, and 4) or they can be subtle, studied, and perhaps even curated especially for this purpose (e.g., Figure 3). Either way, we can see that the Twitter posters are aware of the kinds of symbolic adornments and gestures that get coded by mainstream audiences as "urban," deviant, or dangerous. Hence the overwhelming numbers of gesturing hands and items like hoodies, hats, or doo-rags in the "problematic" pictures. They are also aware of the kinds of symbols that can mediate the presumption of threat of a young Black body. This is why the "acceptable" pictures emphasize smiles, "innocent" others, formal attire, and institutionally sanctioned events (e.g., school or military ceremonies) -all arguably symbols of middle-class respectability.

By looking across the sample as a whole, it becomes clear that there are many ways to be problematic but not as many ways to be seen as socially acceptable. The range

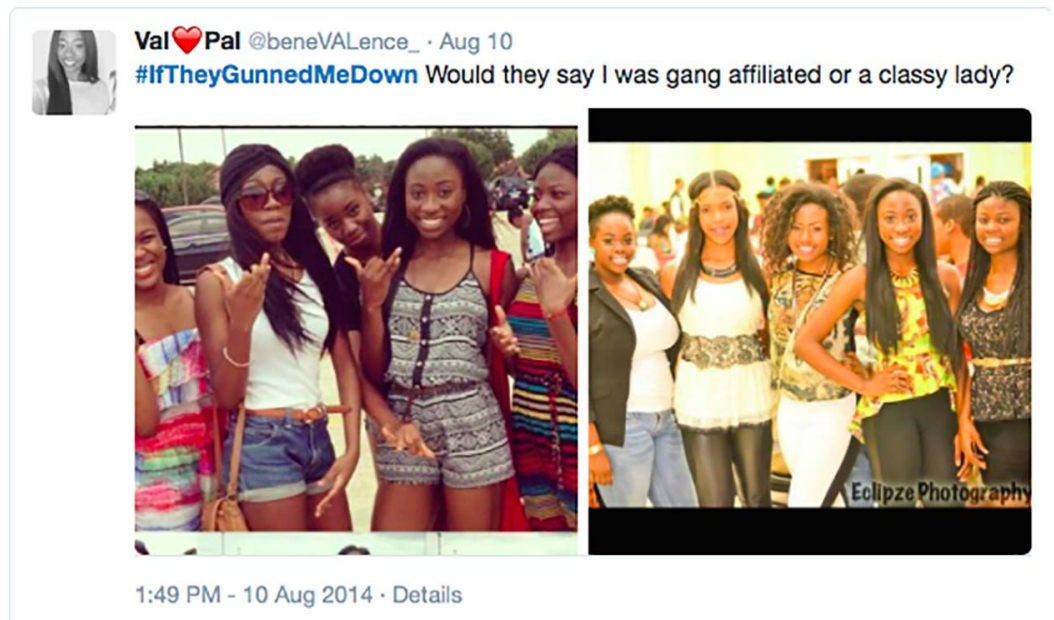

Figure 5 A post from the first day of the hashtag's use. Reproduced by permission of this Twitter user. 
and variation of identities performed in the "acceptable" pictures are quite limited. The eminent sociologist, Erving Goffman, who developed the idea of social interaction as a performance based on scripts, is helpful here. Without using the word directly, Goffman theorizes the basis and effects of stereotypes on those who are stereotyped: "When an actor takes on an established social role, usually he finds that a particular front has already been established for it." 76 In other words, there are scripts and stereotyped expectations for how a particular role ought to be performed. According to the \#ITGMD hashtag's users, the "good" or "respectable" Black young person appears to be one of those roles with only a few scripts. ${ }^{77}$

There is, of course, a commentary on class respectability here. The pictures meant to undermine the way the media might (mis)represent these young people in death generally adopt a middle-class narrative. Unintentionally, perhaps, in an effort to counteract negative narratives of Black youth and display their complexity, decency, and worth, these posts end up collectively reinscribing categories of value-and, therefore, categories of devalue. As Lisa Marie Cacho theorizes, "we are all recruited often unwittingly and/or unwillingly to devalue lives, life choices, and lifestyles because valuing them would destabilize our own precarious claims to and uneasy desire for social value." ${ }^{78}$ By presenting one aspect of themselves as a priori devalued, these young people are proclaiming the value of their other self, or their full complexity. But, in the process, are they fortifying the very idea that the person in the "problematic" half might be somehow more deserving of a gunned down fate? What would it mean, for example, if the young man in Figure 4 were to propose that the lefthand picture by itself shows a person of value, a person worthy of respect, and a person entitled to a full and long life not cut short at the hands of those sworn to protect him? Would that kind of argument function as an even greater form of political resistance against the media? ${ }^{79}$

Although the BLM movement positions itself outside of a politics of respectability paradigm, Black youth's discussion of police violence on Twitter has often been found to differ from activist approaches and rhetoric. A comprehensive study of the networks of Twitter users responding to the events in Ferguson found that "there are substantial populations of Black youth who are simply not being reached by BLM's messages, at least on Twitter." ${ }^{80}$ So despite BLM's best efforts to counter the respectability politics of the Civil Rights Movement and contemporary Black elders and political elites, those ideas remain entrenched in our society. ${ }^{81}$ The young folks participating in the \#ITGMD hashtag still see expectations for respectability in the media's portrayals of them, ${ }^{82}$ and ultimately reinforce its categories through their posts.

Although the hashtag emerged to critique the hypermasculine "thug" narrative the media employed in some reports of Michael Brown's killing-a narrative that generally is gendered as male-the women posting here take it on and revise it as well. ${ }^{83}$ Overall, across gender, there are more similarities than differences; the message of these images is remarkably consistent. Despite the fact that police violence against Black people is consistently presented by the media as a story about men and boys, the images presented here by women show that they are just as fearful of having their character put on trial if they were subject to that fate themselves. The 
gendered differences that do appear, however, suggest that young Black women may feel marginally more able than their male counterparts to present a more "socially acceptable" self by avoiding specific objects that suggest deviance (i.e., drugs or weapons), while many of the young men's posts suggest they feel burdened by the negative stereotypes of Black masculinity that simply exist when they inhabit public space without formal attire or markers of mainstream institutional affiliation. ${ }^{84}$

In fact, the data in this study-produced and shared by young Black people about themselves - suggests that Black youth believe they are essentially presumed deviant by mainstream media unless they intentionally present themselves as otherwise. Only in formal settings that explicitly confirm their educational accomplishments, their professional status, their potential class mobility, or their unequivocal innocence, can they be accepted. It is in these ritual situations that, as Randall Collins explains, "assembly of persons is scheduled and publicly announced; focus of attention is guided by explicit scripts prescribing what is to be done and what is prohibited; and including scripts for how both personal appearance and the physical setting are to be presented." 85 In other words, institutional settings and formal rituals are generally controlled environments with less room for individual expression or unexpected behaviors. The need for prescription and control of Black bodies and our society's ongoing engagement with respectability politics is telling, but perhaps not surprising. ${ }^{86}$

As our society becomes progressively more informal ${ }^{87}$ and as informal "backstage" moments are increasingly pushed into the public eye through our social media and reality TV culture, ${ }^{88}$ Black youth are wondering whether their full humanity can be recognized without many acceptable scripts for self-presentation beyond formal or institutional contexts. In other words, our society seems to have very few, if any, positive models and images of Black youth-particularly low-income Black youth-just "hanging out." And yet, similarly sized and aged white bodies existing in unstructured and informal ways are rarely interpreted as a threat. The pairing of photographs in many of the posts, and one poignant example in particular, ${ }^{89}$ suggests that these young people believe that simply being Black and dressed casually will make them misunderstood by the public; and should that misunderstanding lead to a fatal encounter with the police, the media would further the damage by choosing representative images to paint them in a negative light. Without clear, acceptable scripts for young Black men and women to dress and act informally, it is hard to interpret this collection of posts as anything less than a plea for the recognition of their authors' full humanity.

\section{Conclusion}

The stakes could not be higher; we know that life or death decisions-for example, by police officers-are sometimes made in a split second based simply on one person's perception of another's appearance. We also know that certain symbols, even seemingly innocuous ones, take on different meanings when attached to particular racialized bodies ${ }^{90}$ and that these divergences in meaning have potentially fatal consequences. Through the \#IfTheyGunnedMeDown hashtag following the death of Michael Brown in Ferguson, Black youth across the country demonstrated their 
sophisticated understanding of the semiotics of being viewed as a threat. This aptitude has likely been practiced and developed over time; in fact, we could say that knowing how one version of the self will be visually interpreted compared to another may be the ultimate survival skill in this contemporary landscape of police shootings and other threats to young Black lives. Thus, it is not surprising that we now hear stories of young Black men re-invoking old-school dress codes of respectability by choosing to dress to the nines every day as a "coat of armor" of sorts, a protection against misinterpretation and the threat of state-sanctioned abuse or worse. ${ }^{91}$ Similarly, a new reform movement of public and charter schools serving Black boys draw their dress codes from the elite prep school model, outfitting their students in khakis, blazers, and ties. ${ }^{92}$ Even if these practices of sartorial vigilance are successful in their intentions, they are not without real, lasting physical and mental health costs. ${ }^{93}$

At its core, the \#IfTheyGunnedMeDown hashtag is about representation, reputation, and legacy. The young people posting their dueling self-portraits seem to be aware of their own mortality and concerned about the way they might be remembered if they die young, a fate that must feel even more plausible with each tragic news headline. Du Bois spoke about the "second sight" possessed by African Americans because of their experience beneath the veil of racism and the color line. ${ }^{94}$ The young folks posting \#ITGMD diptychs are demonstrating that "gift"; they are public sociologists of their own racialized and racializing experiences and representation. They are calling out the media for over-simplifying and essentializing their existence, suggesting that, if given the choice, mainstream media would frame them as deviant and threatening rather than something more positive, even-and perhaps especially-in the most tragic of circumstances. And they are fighting back, displaying publicly their complexity, contradictions, code-switching aptitude, and inability to be pinned down to a single category or identity. The self-duality they present inherently points to both the flaws of, and the power of, the respectability politics that continue to frame Black youth in limited ways. And yet, it is clear that although the hashtag began in response to the media, that institution is just one small piece of a larger social world that Black youth believe misunderstands and devalues them with the most grave of consequences.

\section{Acknowledgments}

This article is a revision of research previously published in an online student journal, Powerlines, published by the American Studies Department at the University of Maryland. Powerlines, which is no longer active, was intended to be a works-inprogress publication for students, who retained copyright of their works published therein.

The author thanks Krystal Strong, Randall Collins, Kathy Hall, Shyon Baumann, Michelle Munyikwa, Haley Pilgrim, Teddy Gross, the editors at Powerlines, and the editors and anonymous reviewers at Souls for their invaluable feedback at various stages of this article's development. 


\section{ORCID}

Nora Gross (D) http://orcid.org/0000-0002-9203-2864

\section{Notes}

1. Sam Judah, “\#BBCtrending: The Two Faces of Michael Brown," BBC News, August 11, 2014, http://www.bbc.com/news/blogs-trending-28742301 (accessed March 10, 2018); Layla A. Jones, "\#Iftheygunnedmedown: How the Media Killed Michael Brown," The Philadelphia Inquirer, August 21, 2014, http://www.philly.com/philly/blogs/lifestyle/IftheygunnedmedownHow-media-the-killed-Michael-Brown.html (accessed March 10, 2018).

2. Tanzina Vega, "Shooting Spurs Hashtag Effort on Stereotypes," The New York Times, August 12, 2014, http://www.nytimes.com/2014/08/13/us/if-they-gunned-me-down-protest-on-twitter.html (accessed March 10, 2018).

3. Although Black Lives Matter is now widely recognized as both a hashtag and an offline social movement, at this time in 2014 it was still in its infancy in both respects. One study found that the hashtag \#BlackLivesMatter was used in only 398 public tweets in July 2014, but 52,288 the following month when Michael Brown was killed. [Deen Freelon, Charlton D. McIlwain, and Meredith D. Clark, "Beyond the Hashtags: \#Ferguson, \#Blacklivesmatter, and the Online Struggle for Offline Justice" (School of Communication, American University, Center for Media \& Social Impact, 2016).] A similar study demonstrated that the tweeting of \#BlackLivesMatter increased exponentially again following the non-indictment of former police officer Darren Wilson in November 2014. [Jelani Ince, Fabio Rojas, and Clayton A. Davis, "The Social Media Response to Black Lives Matter: How Twitter Users Interact with Black Lives Matter through Hashtag Use," Ethnic and Racial Studies 40, no. 11 (2017): 1820.]

4. Yarimar Bonilla and Jonathan Rosa, "\#Ferguson: Digital Protest, Hashtag Ethnography, and the Racial Politics of Social Media in the United States," American Ethnologist 42, no. 1 (2015): 7.

5. Juliet Hooker, Race and the Politics of Solidarity (Oxford: Oxford University Press, 2009), 5.

6. Nicholas Mirzoeff, "The Shadow and the Substance: Race, Photography, and the Index," in Only Skin Deep: Changing Visions of the American Self, edited by Coco Fusco and Brian Wallis (New York: Harry N. Abrams, 2003), 111-26; Brian Wallis, "Black Bodies, White Science: Louis Agassiz's Slave Daguerreotypes," in Only Skin Deep: Changing Visions of the American Self, edited by Coco Fusco and Brian Wallis (New York: Harry N. Abrams, 2003), 163-81.

7. Maurice O. Wallace and Shawn Michelle Smith, eds., Pictures and Progress: Early Photography and the Making of African American Identity (Durham, NC: Duke University Press Books, 2012), 3.

8. Nicole R. Fleetwood, Troubling Vision: Performance, Visuality, and Blackness (Chicago: University of Chicago Press, 2011), 6.

9. Larry Gross, "The Ethics of (Mis)representation," in Image Ethics: The Moral Rights of Subjects in Photographs, Film, and Television, edited by Larry Gross, John Stuart Katz, and Jay Ruby (New York: Oxford University Press, 1988), 190.

10. Laura Wexler, "'A More Perfect Likeness': Frederick Douglass and the Image of the Nation," in Pictures and Progress: Early Photography and the Making of African American Identity, edited by Maurice O. Wallace and Shawn Michelle Smith (Durham, NC: Duke University Press Books, 2012), 19.

11. Michael Bennett and Vanessa D. Dickerson, eds., Recovering the Black Female Body: Self-Representation by African American Women (New Brunswick, NJ: Rutgers University Press, 2000). 
12. Lisa Marie Cacho, Social Death: Racialized Rightlessness and the Criminalization of the Unprotected (New York: NYU Press, 2012), 155.

13. TIME Photo, "When One Mother Defied America: The Photo That Changed the Civil Rights Movement," Time Magazine, July 10, 2016, http://time.com/4399793/emmett-till-civil-rightsphotography/ (accessed March 10, 2018).

14. Katharina M. Fackler, "Ambivalent Frames: Rosa Parks and the Visual Grammar of Respectability," Souls 18, no. 2-4 (October 2016): 273.

15. NPR, All Things Considered, "Before Rosa Parks, A Teenager Defied Segregation on an Alabama Bus," National Public Radio, March 2, 2015, http://www.npr.org/sections/codeswitch/2015/02/27/ 389563788/before-rosa-parks-a-teenager-defied-segregation-on-an-alabama-bus (accessed March 10, 2018).

16. NPR, Weekend Edition Sunday, "Before Rosa Parks, There Was Claudette Colvin," National Public Radio, March 15, 2009, http://www.npr.org/2009/03/15/101719889/before-rosa-parksthere-was-claudette-colvin (accessed March 10, 2018).

17. Evelyn Brooks Higginbotham, Righteous Discontent: The Women's Movement in the Black Baptist Church, 1880-1920, Rev. ed. (Cambridge, MA: Harvard University Press, 1994), 187; Melissa V. Harris-Perry, Sister Citizen: Shame, Stereotypes, and Black Women in America (New Haven, CT: Yale University Press, 2011).

18. Higginbotham, Righteous Discontent, 188.

19. Ibid., 187.

20. Randall Kennedy, "Lifting as We Climb: A Progressive Defense of Respectability Politics," Harper's Magazine, October 2015, 31.

21. W. E. B. Du Bois, The Souls of Black Folk, Penguin Twentieth Century Classics edition (Longman, 1903), 8.

22. Shawn Michelle Smith, "Looking at One's Self through the Eyes of Others': W. E. B. Du Bois's Photographs for the Paris Exposition of 1900," in Pictures and Progress: Early Photography and the Making of African American Identity, edited by Maurice O. Wallace and Shawn Michelle Smith (Durham, NC: Duke University Press Books, 2012), 274.

23. Fleetwood, Troubling Vision, 6.

24. José Itzigsohn and Karida Brown, "Sociology and the Theory of Double Consciousness: W. E. B. Du Bois's Phenomenology of Racialized Subjects," Du Bois Review: Social Science Research on Race 12, no. 2 (2015): 235.

25. Cathy J. Cohen, Democracy Remixed: Black Youth and the Future of American Politics (New York: Oxford University Press, 2012), 3.

26. Keeanga-Yamahtta Taylor, From \#BlackLivesMatter to Black Liberation, 1st ed. (Chicago: Haymarket Books, 2016).

27. Elizabeth Day, "\#BlackLivesMatter: The Birth of a New Civil Rights Movement," The Guardian, July 19, 2015, https://www.theguardian.com/world/2015/jul/19/blacklivesmatterbirth-civil-rights-movement (accessed March 10, 2018).

28. Russell Rickford, "Black Lives Matter: Toward a Modern Practice of Mass Struggle," New Labor Forum 25, no. 1 (2016): 35.

29. Barbara Ransby, "The Class Politics of Black Lives Matter," Dissent 62, no. 4 (2015): $31-34$.

30. Osagie K. Obasogie and Zachary Newman, "Black Lives Matter and Respectability Politics in Local News Accounts of Officer-Involved Civilian Deaths: An Early Empirical Assessment," Wisconsin Law Review 2016, no. 3 (2016): 553.

31. “About: Black Lives Matter," Black Lives Matter, n.d., https://blacklivesmatter.com/about/ (accessed October 24, 2017).

32. Jasmine Banks, "Black Kids Don't Have to Be College-Bound for Their Deaths to Be Tragic," TheRoot.com, August 12, 2014, https://www.theroot.com/black-kids-don-t-have-to-becollege-bound-for-their-dea-1790876684 (accessed March 10, 2018). 
33. Shekinah Mondoua, "Systemic Racism Couldn't Care Less About Your Respectability Politics," The Nation, June 16, 2017, https://www.thenation.com/article/systemic-racismcould-care-less-about-your-respectability-politics/ (accessed March 10, 2018); Jamil Smith, "Op-Ed: Respectability Politics Won't Save us from Police Violence," Los Angeles Times, July 14, 2017, http://www.latimes.com/opinion/op-ed/la-oe-smith-respectabilitypolitics-20170714-story.html (accessed March 10, 2018); Zach Stafford, "Respectability Politics Won't Save the Lives of Black Americans," The Guardian, October 12, 2015, https://www. theguardian.com/commentisfree/2015/oct/12/respectability-politics-wont-save-black-americans (accessed March 10, 2018).

34. Black Lives Matter, website.

35. Taylor, From \#BlackLivesMatter to Black Liberation, 159, 106.

36. Joel Anderson, "Ferguson's Angry Young Men," BuzzFeed News, August 22, 2014, https:// www.buzzfeed.com/joelanderson/who-are-fergusons-young-protesters?utm_term=.vjYMjm PKo\#.oqYEPqYK1 (accessed March 10, 2018).

37. “Transcript: Obama's Remarks on Ferguson Grand Jury Decision," The Washington Post, November 24, 2014, https://www.washingtonpost.com/politics/transcript-obamas-remarkson-ferguson-grand-jury-decision/2014/11/24/afc3b38e-744f-11e4-bd1b-03009bd3e984_story. html?utm_term=.ddf14600dfeb (accessed March 10, 2018); Obama's remarks echoed those of Al Sharpton during his eulogy at Brown's funeral (Taylor, From \#BlackLivesMatter to Black Liberation.).

38. Jacqueline L. Urgo, "Black Lives balks as N.J. Lawmaker Wants to Legislate "The Talk," Philly. com, July 3, 2017, http://www.philly.com/philly/news/new_jersey/black-lives-balks-as-n-jlawmaker-wants-to-legislate-the-talk-20170703.html (accessed March 10, 2018).

39. Kennedy, "Lifting as We Climb," 26.

40. Ibid, 27.

41. Rickford, "Black Lives Matter," 39.

42. Alicia Garza, "A Herstory of the \#BlackLivesMatter Movement," The Feminist Wire, October 7, 2014, http://www.thefeministwire.com/2014/10/blacklivesmatter-2/ (accessed March 10, 2018).

43. Freelon, McIlwain, and Clark, "Beyond the Hashtags," 76.

44. Melissa Brown et al., "\#SayHerName: A Case Study of Intersectional Social Media Activism," Ethnic and Racial Studies 40, no. 11 (2017): 1831-46, doi:10.1080/01419870.2017.1334934; Kimberlé Williams Crenshaw and Andrea J. Ritchie, "Say Her Name: Resisting Police Brutality against Black Women" (New York: African American Policy Forum, July 2015).

45. Axel Bruns and Katrin Weller, "Twitter Data Analytics-or: The Pleasures and Perils of Studying Twitter," Aslib Journal of Information Management 66, no. 3 (2014); Maeve Duggan, "Mobile Messaging and Social Media-2015" (Pew Research Center, August 19, 2015), http://www.pewinternet.org/2015/08/19/mobile-messaging-and-social-media-2015/ (accessed March 10, 2018).

46. Duggan, "Mobile Messaging and Social Media"; Black women, in particular, use Twitter more than any other group (Sherri Williams, "Digital Defense: Black Feminists Resist Violence With Hashtag Activism," Feminist Media Studies 15, no. 2 [2015]: 341-44.).

47. Sarah Florini, “Tweets, Tweeps, and Signifyin': Communication and Cultural Performance on 'Black Twitter," Television \& New Media 15, no. 3 (2013): 223-37; Sanjay Sharma, "Black Twitter?: Racial Hashtags, Networks and Contagion," New Formations: A Journal of Culture/Theory/Politics 78, no. 1 (2013): 46-64.

48. Roderick Graham and 'Shawn Smith, "The Content of Our \#characters: Black Twitter as Counterpublic," Sociology of Race and Ethnicity 2, no. 4 (2016): 433-49.

49. Sharma, "Black Twitter?"

50. Andre Brock argues that the evolution of the hashtag is what "led to the 'discovery' of Black Twitter." [Andre Brock, "From the Blackhand Side: Twitter as a Cultural Conversation," Journal of Broadcasting \& Electronic Media 56, no. 4 (2012): 529-49, at 534]. Other research 
on Black activist hashtags include: Rachel Kuo, "Racial Justice Activist Hashtags: Counterpublics and Discourse Circulation," New Media \& Society 20, no. 2 (2018): 495-514; Nikita Carney, "All Lives Matter, but so Does Race: Black Lives Matter and the Evolving Role of Social Media," Humanity \& Society 40, no. 2 (May 2016): 180-99; Tara Conley, "From \#RenishaMcBride to \#RememberRenisha: Locating Our Stories and Finding Justice," Feminist Media Studies 14, no. 6 (2014): 1111-13; Melissa Brown et al., "\#SayHerName: A Case Study of Intersectional Social Media Activism," Ethnic and Racial Studies 40, no. 11 (2017): 1831-46; Freelon, McIlwain, and Clark, "Beyond the Hashtags"; Sarah J. Jackson and Brooke Foucault Welles, "Hijacking \#myNYPD: Social Media Dissent and Networked Counterpublics: Hijacking \#myNYPD," Journal of Communication 65, no. 6 (2015):932-52.

51. Bonilla and Rosa, “\#Ferguson," 5; Sharma, "Black Twitter?" 50.

52. Conley, "From \#RenishaMcBride to \#RememberRenisha."

53. Bonilla and Rosa, "\#Ferguson."

54. Michael S. Ball and Gregory W. H. Smith, Analyzing Visual Data (Newbury Park, CA: SAGE Publications, 1992).

55. Douglas Harper, "Visual Sociology: Expanding Sociological Vision," The American Sociologist 19, no. 1 (1988): 65.

56. Shaun R. Harper, "Success in These Schools? Visual Counternarratives of Young Men of Color and Urban High Schools They Attend," Urban Education 50, no. 2 (2015): 139-69.

57. Herman W. Smith, Strategies of Social Research: The Methodological Imagination, 2nd ed. (Englewood Cliffs, NJ: Prentice-Hall, 1981).

58. Race is, of course, a socially constructed set of categories, but racialization processes produce social realities that result in a certain degree of shared understandings (Michael Omi and Howard Winant, Racial Formation in the United States: From the 1960s to the 1990s [New York and London: Routledge, 1994]). Therefore, although it is an imprecise process, for the purposes of this project, I have selected images posted by individuals whom I identify as Black and appearing to be under 30 years old approximately.

59. Though, again, an imperfect method, here I have designated gender based on my own perception of the images and, when necessary, information gleaned from the tweeters' profiles.

60. Carney, "All Lives Matter, but so Does Race"; Sarah J. Jackson and Brooke Foucault Welles, "\#Ferguson Is Everywhere: Initiators in Emerging Counterpublic Networks," Information, Communication \& Society 19, no. 3 (2016): 397-418.

61. Ince, Rojas, and Davis, "The Social Media Response to Black Lives Matter"; Freelon, McIlwain, and Clark, "Beyond the Hashtags"; Brown et al., "\#SayHerName."

62. Anecdotally, I noticed that over the course of the several days following the original \#ITGMD post, the tenor of the posts shifted with more white people participating, the addition of posts that seemed to be satirizing or making light of the original intention, and an uptick in posts that incorporated pictures of celebrities rather than the tweeters themselves. This shift in the meaning of protest hashtags over time has been documented in other research (Carney, "All Lives Matter, but so Does Race.")

63. Erving Goffman, The Presentation of Self in Everyday Life (New York: Anchor, 1959), 2.

64. A diptych generally describes a flat artwork (i.e., painting, drawing, photograph) presented in two panels, usually of the same size. Throughout the history of art, diptychs have been used to present two themes related in subject matter or meaning or, sometimes, in opposition to each other.

65. Bernard Berelson, Content Analysis in Communication Research (Glencoe, IL: Free Press, 1952), 18.

66. Bruce L. Berg and Howard Lune, Qualitative Research Methods for the Social Sciences, 8th edition (Boston: Pearson, 2011); Siegfried Kracauer, "The Challenge of Qualitative Content Analysis," The Public Opinion Quarterly 16, no. 4 (1953, 1952): 631-42.

67. Ball and Smith, Analyzing Visual Data, 27. 
68. Although this article focuses on patterns across the image types, a closer analysis of the pairs of images themselves would likely be a fruitful area of further study.

69. Goffman, The Presentation of Self in Everyday Life; Roland Barthes, Camera Lucida: Reflections on Photography, First edition (Hill and Wang, 1981), 10.

70. Interestingly, military affiliation was about three times more frequent in the "acceptable" images presented by women in the sample than by men. This is compared to the other major marker of institutional affiliation-school graduation paraphernalia-which was found in equal numbers across gender. Future research might explore whether, for Black men, the violence associated with the military might be seen as counteracting its positive associations.

71. The first five categories listed here are not mutually exclusive as someone might be both at graduation and giving a speech (as in Figure 1, top) or wearing a military uniform and posing for a professional institutional photograph (as in Figure 2, right). Taken together, those five categories account for $49 \%$ of the sample of "acceptable" pictures.

72. This is not to say that the symbols I describe as possibly illegal, offensive, or dangerous in any way make the individuals in those images at all deserving of violence at the hands of the police. I am referring here only to my interpretation of the argument the hashtag users are themselves making through the visual juxtaposition.

73. Future research ought to more intentionally consider how self representation might differ by age, race, or gender-particularly as the hashtag shifted in meaning over time-in ways that my unbalanced sample would not allow.

74. Du Bois, The Souls of Black Folk, 8 .

75. Kimberly J. Crenshaw, "Mapping the Margins: Intersectionality, Identity Politics, and Violence Against Women of Color," in Critical Race Theory: The Key Writings That Formed the Movement, edited by Kimberle Crenshaw et al. (New York: The New Press, 1996), 357-83; Patricia Hill Collins, Black Feminist Thought: Knowledge, Consciousness, and the Politics of Empowerment (New York: Routledge, 2000).

76. Goffman, The Presentation of Self in Everyday Life, 27.

77. Kwame Anthony Appiah, "Race, Culture, Identity: Misunderstood Connections," in Color Conscious, edited by Kwame Anthony Appiah, Amy Gutmann, and David B. Wilkins, Reprint edition (Princeton, NJ: Princeton University Press, 1998), 30-105.

78. Cacho, Social Death, 27.

79. Cathy J. Cohen, "Deviance as Resistance: A New Research Agenda for the Study of Black Politics," Du Bois Review 1, no. 1 (2004): 27-45.

80. Freelon, Mcllwain, and Clark, "Beyond the Hashtags," 5, 77.

81. Obasogie and Newman, "Black Lives Matter and Respectability Politics in Local News Accounts of Officer-Involved Civilian Deaths."

82. Interestingly, none of the \#ITGMD posts in this sample are marked with any specific references to \#BlackLivesMatter. Future research might investigate whether posts that specifically align themselves with Black Lives Matter or related protest movements differ at all in their engagement with respectability politics.

83. In other words, the \#ITGMD hashtag did not develop in response to the narrative hypersexuality, which Black women have historically countered by invoking a politics of respectability (Higginbotham, Righteous Discontent; Harris-Perry, Sister Citizen).

84. Further investigation and a more balanced sample would be needed to make more concrete and complex claims about gender differences.

85. Randall Collins, "Four Theories of Informalization and How to Test Them," Human Figurations 3, no. 2 (2014), http://hdl.handle.net/2027/spo.11217607.0003.207 (accessed March 10, 2018).

86. It is here that we might choose to read into the absence of Black hands in so many of the "acceptable" pictures because hands may function as a symbol of agency or power. This too would be a worthy area of future study. 
87. Collins, "Four Theories of Informalization and How to Test Them"; Cas Wouters, Informalization: Manners and Emotions since 1890 (London: Sage, 2007).

88. A. Marwick and d. boyd, "To See and Be Seen: Celebrity Practice on Twitter," Convergence: The International Journal of Research into New Media Technologies 17, no. 2 (2011): 139-58; A. E. Marwick and d. boyd, "I Tweet Honestly, I Tweet Passionately: Twitter Users, Context Collapse, and the Imagined Audience," New Media \& Society 13, no. 1 (2010):114-33.

89. https://twitter.com/__PantheR/status/498618925634969600 (accessed March 10, 2018).

90. Bonilla and Rosa, "\#Ferguson."

91. David Yi, "Black Armor: Some Black American Men Are Dressing up to Deflect Negative Attention, as a Conscious Means of Survival," Mashable, 2015, http://mashable.com/2015/ 08/08/black-men-dressing-up-police/ (accessed March 10, 2018).

92. Edward Fergus, Pedro A. Noguera, and Margary Martin, Schooling for Resilience: Improving the Life Trajectory of Black and Latino Boys (Cambridge, MA: Harvard Education Press, 2014).

93. Hedwig Lee and Margaret Takako Hicken, "Death by a Thousand Cuts: The Health Implications of Black Respectability Politics," Souls 18, no. 2-4 (2016): 421-45. Further, the "psychic pain" experienced by Black folks who hold images of themselves that they know are different from how they are viewed by others has long been documented (Harris-Perry, Sister Citizen, 96).

94. Du Bois, The Souls of Black Folk, 8.

\section{About the Author}

Nora Gross is a Ph.D. student in Education and Sociology at the University of Pennsylvania, researching race, gender, and trauma in urban schooling contexts. She is also a documentary filmmaker and former high school teacher. 